\title{
Research
}

\section{Traditional Wisdom: Protecting Relationships with Wilderness as a Cultural Landscape}

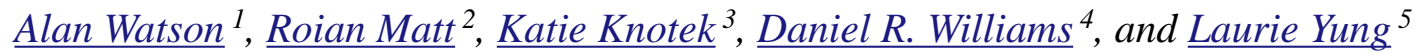

\begin{abstract}
Interviews of tribal and nontribal residents of the Flathead Indian Reservation in Montana, U.S., were conducted to contrast the meanings that different cultures attach to the Mission Mountains Tribal Wilderness. Legislation that created a national system of wilderness areas (in 1964 and still growing) was conceived, supported, and enacted by a fairly distinct social group generally residing in urban areas and schooled in modern civilization's scientific model and relationship with nature. The places this legislation protects, however, provide many other poorly recognized and little understood meanings to other parts of society. There is a link between indigenous people and nature that is not described well in this legislation or management policy in most places. The Wilderness Act suggests that these protected areas should be "untrammeled," or unmanipulated, unfettered, when in fact it is common knowledge that, for most areas in North America, indigenous people have intervened, with respect, for generations. The Mission Mountains Tribal Wilderness in Montana, though not part of the National Wilderness Preservation System, was designated to protect many of these same values but also extend to protect important cultural meanings assigned to this wild landscape. Protecting the relationship between indigenous people and relatively intact, complex systems, which we commonly refer to as wilderness in North America, can be an important contributor to sustainability of the landscape and cultural heritage.
\end{abstract}

Key Words: cultural resources; landscape meanings; protected area; public involvement; tribal land management

\section{INTRODUCTION}

Wilderness in the United States is frequently identified with The Wilderness Act (Public Law 88-577), which was passed in 1964. The Wilderness Act immediately established wilderness protection for over 9 million acres of federal land, mostly in the western United States. More importantly, this Act established the National Wilderness Preservation System (NWPS) and a process whereby subsequent Congresses could add acreage. Today, the NWPS contains more than 106 million acres, comprised of lands administered by the Department of Agriculture Forest Service, and the Department of Interior National Park Service, Bureau of Land Management and Fish and Wildlife Service. Over half of that acreage was added to the NWPS in one single act, the Alaska National Interest Lands Conservation Act of 1980 (ANILCA), and is located in Alaska. Generally, wilderness is characterized by the original Act as a place where man is a visitor who does not remain; an untrammeled place defined by its opportunities for solitude or primitive and unconfined recreation. ANILCA was unique in acknowledging and providing for continued traditional uses and access methods by rural residents of Alaska, but many managers have approached subsistence use as a legislated special provision exception to The Wilderness Act that must be accommodated (Dawson and Hendee 2009).

Research in the United States on wilderness and wilderness values has mostly ignored the issue of indigenous peoples' relationships with lands protected as wilderness (Watson et al. 2003), although some literature has highlighted the history of the relationship between native people and public

\footnotetext{
${ }^{1}$ Aldo Leopold Wilderness Research Institute, ${ }^{2}$ The Confederated Salish \& Kootenai Tribes of the Flathead Nation, Forest Management Department, ${ }^{3}$ Powell Ranger District, Clearwater National Forest, ${ }^{4}$ Rocky Mountain Research Station, USDA Forest Service, ${ }^{5}$ Department of Society \& Conservation, College of Forestry \& Conservation, The University of Montana
} 
lands management agencies (Keller and Turek 1998) and the relationship between native people and nature in general (Carlson 1998). Wilderness research has progressed, however, from early studies in the 1960s that focused almost entirely on managing recreational uses of wilderness to more recent investigations of more broad societal values (Wright 2000).

Still, very little research has been conducted on the interaction between traditional uses and other wilderness uses or the values associated with wilderness by indigenous people. Use of wilderness by indigenous people for traditional purposes has been treated largely as a special provision or nonconforming use. It does not conform to the wilderness ideal as represented in Euro-American philosophy (Berkes 2008). Traditional wilderness recreation research has provided little insight into the broad array of value orientations held by a multitude of stakeholders toward wilderness resources (Watson 1995, Watson et al. 2003). Berkes (2008) concluded that there is a need to encourage pluralistic ways of thinking about our relationships with wilderness.

The specific purpose of the project described here is to contribute to the transition from invisibility to transparency, as described by Turner et al. (2008), through development of approaches more effective at describing what matters most to indigenous people in meaningful ways to influence conservation decision making. A project is described to contrast meanings associated with wilderness ascribed by tribal and nontribal residents of the Flathead Indian Reservation in Montana, United States. This is part of a larger project to capture tribal meanings attached to wilderness and a related buffer zone in order to guide sensitive decisions about fuel treatments to reduce fire hazards in the buffer zone and increase potential for restoration of fire in the wilderness as a natural component of that environment (Watson et al. 2008).

\section{Wilderness research}

In an attempt to demonstrate the value of this project to contrast tribal and nontribal orientations toward wilderness, it is first of all desirable to proceed through a brief description of the evolution of wilderness social science research, discuss the relationship between wilderness and traditional knowledge, and review some limited research that suggests how designation of wilderness might contribute to protection or restoration of cultural landscapes, before introducing a specific case study on the Flathead Indian Reservation in Montana.

Introduction to the legislative history, debate, and philosophical influences behind The Wilderness Act became part of U.S. academic programs in the 1970 s, and today there are many universities with basic and advanced education programs with emphases on scientific research and academic exploration of the wilderness concept. The wilderness community is also growing internationally: the World Wilderness Congress met for the 9th time in Mexico in 2009 (Watson et al., in press), the International Journal of Wilderness recently celebrated its 15th year of publication, the wilderness community has recently spread in interest in Asia (Watson et al. 2009a, b), and a chapter in the Fourth Edition of the Wilderness Management textbook (Dawson and Hendee 2009) contained an expanded discussion on progress and intent of many countries around the world in protecting lands and water as wilderness (Martin and Watson 2009). The Confederated Salish and Kootenai Tribes of western Montana have long been international leaders among indigenous advocates for wilderness protection (McDonald 1995, Martin 2006, Tanner 2008).

The Wilderness Act referenced the problem of "increasing population, accompanied by expanding settlement and growing mechanization" as the justification for establishing a system of areas protected for their wilderness character. The primary purpose was "to secure for the American people of present and future generations the benefits of an enduring resource of wilderness." Most initial research was aimed at understanding how recreation visitors themselves influenced the ability of managers to protect the resource and the experiences they were directed to provide there. A very simple matrix with a small number of wilderness attributes (e.g., natural vegetation, soil conditions, and lack of crowding) and what was seen initially as the primary threat to these attributes (number of visitors and their behaviors) was advanced to form a planning framework referred to as the Limits of Acceptable Change (Stankey 1973, Stankey et al. 1985, McCool and Cole 1998).

Expansion of this simple matrix occurred in 1993, as a new generation of scientists transformed the 
Aldo Leopold Wilderness Research Institute from what was formerly a Forest Service research unit focused almost entirely on recreation uses and impacts in wilderness. The Leopold Institute was tasked to provide broader knowledge on challenges facing wilderness managers. A more complex matrix that described wilderness and threats to it was presented at the Fifth World Wilderness Congress by Landres et al. (1994) (Fig. 1). This matrix was presented as both an interpretation of the legislative definition of wilderness and a framework for guiding monitoring of important threats to wilderness character. While this matrix represented the primary model for U.S. wilderness, Rothenberg (1995) concluded that the only thing everyone at the $5^{\text {th }}$ World Wilderness Congress agreed on was that they all disagreed on a definition of wilderness. The U.S. definition and implementation following the Wilderness Act had caught the imagination of the world, but the need for adaptations to other cultures was evident.

This expanded matrix included those attributes of wilderness character most commonly appearing in the literature for the previous 30 years, but additionally included air, aquatic systems, animals, landscape characteristics, and cultural sites. The threats to these attributes that were identified extended well beyond recreation visitors and their impacts to include fire exclusion, pollutants, domestic livestock, adjacent land management, water control projects, mineral activities where they were allowed, and invasive species. Watson and Williams (1995) described an expanded conceptualization of how people related to wilderness places beyond a recreation purpose. Much of recreation research in the United States had historically been based on the assumption that ventures into the outdoors were recreation goal-oriented (Watson 2001), but Watson and Williams (1995) were suggesting a more complex analysis of the wilderness experience and influences on it; they suggested that the American ideal of wilderness as an area where "man himself is a visitor who does not remain" should be examined across cultures.

\section{Traditional knowledge and wilderness}

To expand our understanding of wilderness across other cultures, Huntington (2002) worked to tease out the relationship between traditional knowledge and wilderness protection among North American indigenous communities. Building upon this effort, Watson and others (2003) focused more specifically on how wilderness protection mediated some of the negative influences (threats) inherent in the relationship between indigenous people in the north and wilderness landscapes.

Watson et al. (2003) emphasized the kincentric ecological principles described by Salmon (2000) that suggest indigenous people have traditionally most likely experienced the environment as a whole, that all the parts of the system are interrelated. Traditional knowledge can be seen as the quantitative information about these interrelationships that has accumulated across generations of people. In describing this knowledge, however, Turner et al. (2000) suggested that it is not easily subject to fragmentation, as we most commonly do in western science approaches (e.g., developing matrices of attributes and threats to define the wilderness concept). Turner et al. (2000) suggested that traditional wisdom is acquired and demonstrated through understanding and maintenance of relationships with complex natural systems, such as wilderness, and that these systems are dependent on traditional knowledge to fully understand forces of change and likely response of the system.

Scientists have partitioned wilderness into attributes and threats to guide management and research. Now, however, study is expanding to other orientations to these same places, and recently a small number of realizations have emerged: (1) Not all cultures have a dualistic/binary conceptualization of wild nature in which man is a visitor who does not remain. That dualism emerges from a very western perspective, from urban visitors to the natural landscape who return to the urban environment after a visit. The idea of a visit is not necessarily accepted by people who have hunted and gathered on the same land for many generations. The dominant American cultural perspective on wilderness cannot provide a universal, crosscultural concept of conservation (Berkes 2008). (2) For many people, wilderness does not generally meet the ideal of being untrammeled. That term is also of a specific cultural origin that represents the orientation toward wilderness of the politically astute people who facilitated passage of The Wilderness Act. Indigenous people are often more likely to describe their relationship with nature as one of human intervention with respect (Watson et al. 2003, Clarke and Slocombe 2009) to protect or restore the values they derive from such a 
Fig. 1. Articulating attributes and threats to wilderness character through a monitoring framework (Landres et al. 1994).

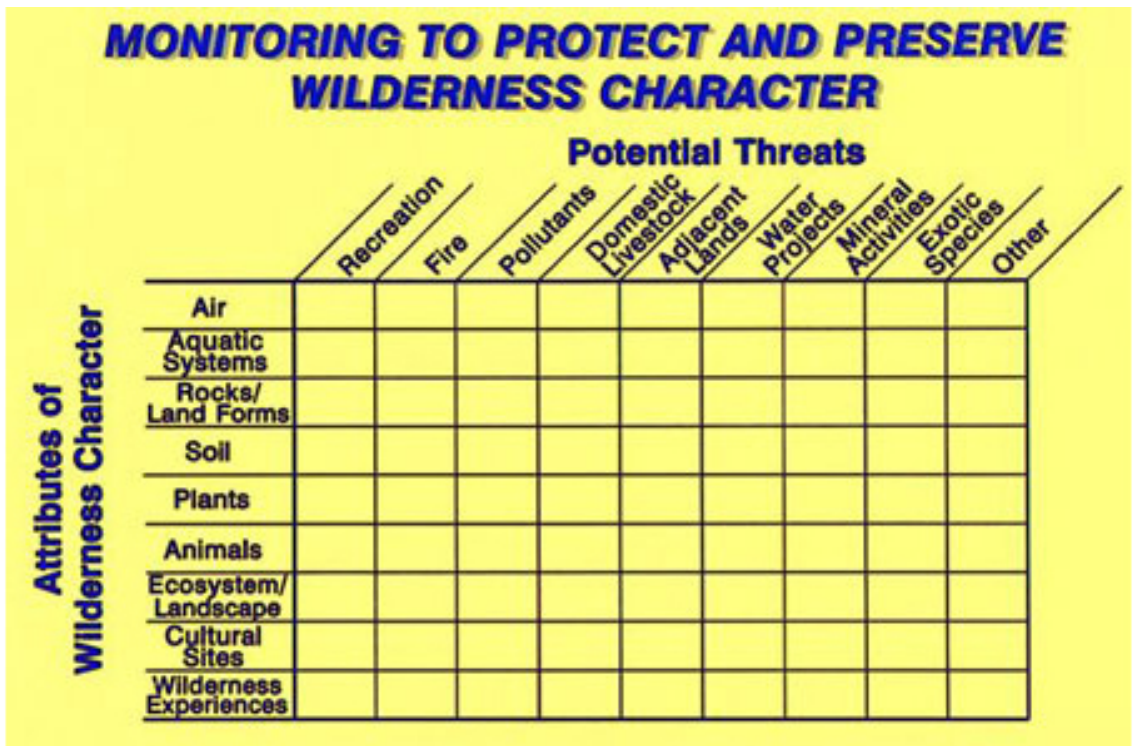

relationship. (3) Traditional knowledge represents a constantly evolving way of thinking about the relationship between people and nature (Watson et al. 2003). It is not a matter of simply understanding past relationships, but can also be expanded to anticipate the effects of various threats (such as environmental change, political power, technology, and resource management policies) on the interrelationships between elements of a complex system. (4) Multiple orientations to wilderness exist and should be embraced. Whereas one cultural group was very influential in establishing legal protection for these lands and waters and justified that protection through the specific orientation they held for these places, there are other orientations toward these same places that we need to understand and appreciate (Watson 2004, Berkes 2008).

Any relationship between humans and nature could become endangered due to the absence of a single component of a system or threats to a single value ascribed to that place. Although traditional knowledge can be important in protecting that single plant or value, traditional wisdom is demonstrated by protecting the relationship between humans and the relatively intact, complex system of human and nonhuman forms found in formally protected wilderness.

\section{Cultural landscapes}

Although wilderness is often defined by Americans as a natural landscape, it might also be considered a cultural landscape by some. Küster (2004) suggests that natural landscapes are mainly shaped by natural processes, whereas cultural landscapes are more or less intensively influenced by humans. Because every landscape on earth can now be regarded as a cultural landscape due to a variety of atmospheric influences as well as agricultural and development practices, it has become increasingly difficult to differentiate between natural and cultural landscapes. Designation of wilderness is sometimes described as a cultural decision to transform a cultural landscape into one dominantly influenced by natural dynamics (Küster 2004). Cultural meanings are often assigned to places and have been communicated simply through mention of these place names in some native communities (Basso 1996). Among the Apache, Basso (1996) believes cultural meanings have accrued, and never stop accruing, from lives spent interacting with places. Wilderness designation, which is a cultural decision to allow natural forces be the primary determinant of change, can also be seen as a way to protect a landscape full of cultural meanings. 
Whiting (2004) described the meanings of wilderness the Qikiktagrugmiut (Inupiaq people of Kotzebue, Alaska) attach to wilderness of the Western Arctic Parklands. From interviews with the most active hunters and gatherers in that community, meanings such as identity, traditional way of life, survival, personal growth, expression of humility, mental and physical health, and independence and self-sufficiency emerged. Some of the factors of influence on these meanings included agency restrictions and regulations, modern technology, the National Park Service's lack of understanding of "way of life" of native people, global warming, globalization, lack of respect by outsiders, sport hunting, and increasing numbers of visitors and development pressure, both for commercial purposes and for energy exploration. In this Qikiktagrugmiut example, the factors of influence extend well beyond those under control of managers and help us understand a specific cultural definition of a landscape protected for its wilderness character.

\section{Wilderness and the Flathead Indian Reservation}

The Confederated Salish and Kootenai Tribes (CSKT) are composed of the Bitterroot Salish, the Pend d'Orielle, and Kootenai Tribes. According to McDonald (1995), these people traditionally occupied a 20-million-acre homeland stretching from central Montana to eastern Washington and north into Canada. Through the Hellgate Treaty in 1855 , they became entrenched in a small remnant of those lands, what is now the Flathead Indian Reservation, containing about 1.243 million acres in western Montana.

In 1982, the Tribal Council overwhelmingly approved a motion to protect 92,000 acres of reservation lands as wilderness (Fig. 2). The Mission Mountain Tribal Wilderness, which extends along the face of the Mission Mountains to the crest, was also protected by the Mission Mountain Tribal Wilderness Buffer Zone in 1987. This buffer zone is about 22,000 acres and was intended to protect the wilderness from outside influences, primarily human activities and development on the valley floor. Immediately east of the Tribal Wilderness lies the federally protected Mission Mountain Wilderness (74,000 acres) of the Flathead National Forest. Restoration of fire and other aspects of this entire ecosystem requires better understanding of how the public, both tribal and nontribal residents on the reservation, view the meanings of this landscape. Subsequent research is aimed at understanding how those meanings relate to public response to proposed management policies. On the reservation, tribal member support of tribal government programs in forestry, fire, and wildland recreation is important to maintain trust in government operations.

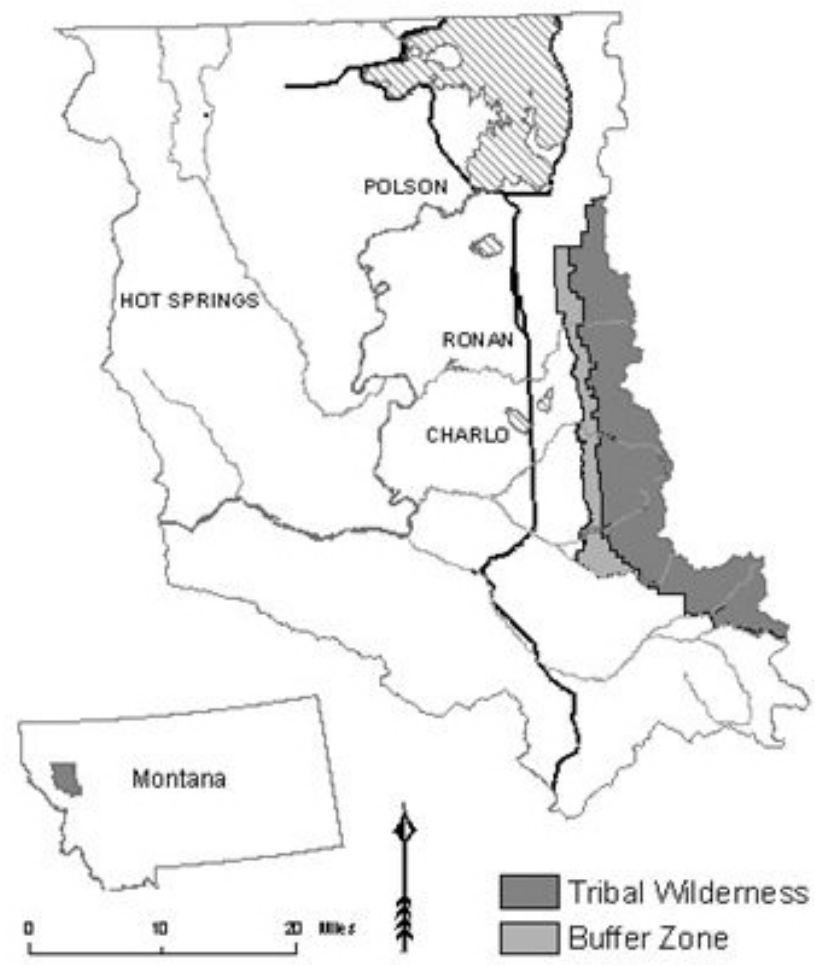

Fig. 2. Mission Mountain Tribal Wilderness within the Flathead Indian Reservation, Montana.

\section{METHODS}

Individual and community meanings attached to the Mission Mountains landscape by tribal members and nontribal reservation residents were assessed. The intention of this research is to contribute to development of a social data layer for planning and application of fuel treatment and fire management on the Flathead Indian Reservation. The methods described here demonstrate the value of the suggestion by Turner et al. (2008) that, by providing opportunities for individuals to express, in their own 
words, feelings about the meanings they ascribe to a landscape, they can enable others to understand their interests better.

\section{Data collection}

Semistructured interviews were conducted with tribal members and findings compared with those of nontribal reservation residents who are recognized as community members possessing locally important knowledge about the Mission Mountains landscape. Following the work of Lewis and Sheppard (2005), key informants were selected to meet the following criteria:

1. Knowledge - Collectively, they possess the necessary understanding of and appreciation for traditional tribal and nontribal meanings associated with the Mission Mountains landscape.

2. Role in the community - Individually, due to their position in their community (tribal or nontribal), they have wide exposure to a range of tribal and nontribal perspectives and perceptions of the landscape.

3. Communication ability - Individually, they are comfortable communicating with outsiders and are capable of discussing relevant research issues in depth.

Interviews (Table 1) were conducted with one or two individuals at a time and were scheduled at the convenience of the interviewees. A small number of these key informants received pay for providing their input, based on elder status.

\section{Analyses}

Key informant interviews were tape-recorded, transcribed verbatim, and organized using the software program QSR NVivo, Version 2.0. Completed transcripts were reviewed, by those interviewees who were willing, for verification of their accuracy. Qualitative analysis began with a detailed read-through of all the interview transcripts. Insights into individual interviews were gained in the context of all others. Close comparison of individual interviews revealed a set of categories for organizing the analysis (May 2002). Segments of the text were then assigned textual "codes" that are representative of the revealed meanings.

\section{RESULTS}

There were 10 targeted interviews with nontribal members and 12 with tribal members, though one couple interviewed was mixed; he was nontribal and she was a tribal member. Tribal members represented the mix of Native American heritage present on the reservation. In the presentation of results, those items in italics are example direct quotes from single interview respondents $(\mathrm{R})$ or from interviews with multiple respondents $(\mathrm{R} 1$ and R2); "I" indicates statements or questions by the interviewers.

These tribal members were mostly born within this community and many had lived most of their lives there. On the other hand, nontribal community members varied in the length of time they had lived on the reservation. Many of the nontribal members are in contrast with most of the tribal members, who have family connections to these lands well beyond the past century.

\section{Tribal meanings ascribed to the Mission Mountain Tribal Wilderness}

Some initial categories of meanings were collapsed into smaller numbers of categories, and some were added during the analysis process as the meanings emerged. This is an interpretive process, so the category titles are not as important as the evidence presented in the words of the people interviewed. The meanings tribal members attached to the wilderness are described here as (1) protecting nature and culture; (2) functional, emotional, and symbolic attachments; (3) wildlife and watershed protection; and (4) access, beauty, privacy, and recreation.

\section{Protecting nature and culture}

This broad category of meanings largely flows from the commonly believed intent of wilderness protection to stop extensive and intensive logging practices witnessed elsewhere on the reservation. The words "protection" and "preservation" were 
Table 1. Interview guide questions

Tell me about the tribal wilderness (Describe it for me):

1. What can you tell me about the history of the tribal wilderness?

2. Why did the tribes protect this area as wilderness?

3. Do you ever visit the tribal wilderness?

4. If so, what do you do when you visit the wilderness?

5. Are there places you like to go in the wilderness?

6. Why do you like to go to these places?

7. Are there places you don't go in the wilderness?

8. Why don't you go to these places?

9. Did you used to go to these places?

10. Do these places have meaning to you?

11. Are there things you would like to do that aren't allowed in the wilderness?

12. If so, is there another place on the reservation where you can do these things?

13. What do you think is important about the wilderness? Why?

14. What do you value about living near this wilderness area?

15. How do you feel about the current condition (e.g., vegetation, wildlife, evidence of fire, number of people, etc.) of the wilderness?

16. Is there anything about the wilderness you would change?

used often by tribal members and referred to protection of intact natural and cultural resources of the Mission Range. Protection of natural and cultural resources both depend on a natural system. The following is an example:

R: So that's why they decided to put one-fifth of our reservation into tribal wilderness protection. Protection, not only for our children but for the tribe. (Interview 9)

R: But not just for the culture. I would hope that in my insights I think more holistic than that. I wouldn't want to be culture bound in that regard, I don't think. I think that it's the way it's evolved for 10,000 generations, and I think that that's right philosophically, and that it simply should stay that way. If it's what helps me breathe and helps my greatgrandchildren breathe, then I want it to stay like that. (Interview 22)

Functional, emotional, and symbolic attachments

Tribal people described some things they receive from the wilderness as very functional. Sometimes they go there for medicinal or food plants because that is where they grow. People go to the wilderness because that is where they have found meat and plants they need. They talk about game there, or animals, not wildlife. 
R: Without areas like this, that are necessary to conduct some of your ceremonies, some areas that you need to go to gather the medicinal and food plants that are necessary in the survival of our culture, without that I think our culture would rapidly disappear. And I think any culture in any country it's necessary to have areas like this where you can establish or continue to reestablish your existence as who you are... We use a lot of the plants for medicines. And, of course, the animals, we have them to eat. (Interview 1)

Sometimes people describe their attachment to the wilderness as more emotional, not because it is a wilderness, but because they have a personal relationship with the area. Usually among tribal members, that relationship far preceded wilderness designation, linking them to parents and grandparents.

$R:$ It's an area where there's an opportunity to walk in the footsteps of our elders and ancestors that have come before us. (Interview 16)

On the other hand, some of the attachments to the wilderness are very symbolic. It is symbolic of culture and spirituality. It goes beyond the functional values of plants and animals, and even beyond the emotional values individuals place on the area. It is valuable because it provides a cultural connection for a community of people and a legacy for future generations. The Mission Mountain Tribal Wilderness is a symbol of a relationship with a much larger area for a much longer time.

R: So it provides many different things for our culture. It provides not only medicinal and food plants, but it also provides spiritual areas where people continue to utilize and to go and which is necessary in our, I guess if you want to call it, our spirituality, our religion. I guess, it's important to have these areas. And with the population growing as it is today, areas like this are becoming very important, very, I guess they're starting to disappear, so establishing the Wilderness helps protect those areas for the, I guess the survival of, the way I look at it is the survival of Indian people, of the Salish Pend d'Oreille people. (Interview 1)

R: So there's this promise to our children. And as Nelson Mandela said, promises to children should never be broken. And these are children yet to come that we've promised a wilderness. And I think that we need to honor that promise. (Interview 16)

\section{Wildlife and watershed protection}

Tribal members also described wildlife values of the wilderness, particularly as a haven for bears, a cultural keystone species for many North American native people (Garibaldi and Turner 2004). Similarly, there are subsistence and appreciative values associated with free-flowing water. These off-site contributions to quality of life that tribal members described as meanings of the wilderness move us into a slightly different realm.

R: But this, if it's untouched, it means that the animals will be safely taken care of through nature... especially the bears, they get kind of aggressive and people really aren't afraid of them because they come down, you know. And if you keep it to wilderness, they'll have all the food that they need. (Interview 12)

$R$ : And that's why we have river honoring, to talk about the water, how important it is to our livelihood. And that snow and everything that goes down, well, it helps the people down here, too. And helps us to keep our buffer zone. Because if we don't keep our wilderness there, all the water will shut off and go down to the ocean. You won't have time to get it to where you would like it to go. But water is important. (Interview 12)

\section{Access, beauty, privacy, and recreation}

Tribal members do attach appreciative meanings to the wilderness. They think of it as "close to home," therefore providing easy access. The high mountain portions of this wilderness loom majestically above the Mission Valley, always a reminder of the wilderness there.

$R$ : So, and most people in the valley are in that situation where they live in the community of Ronan, Pablo. If you look at how it runs north and south, literally you can be in the wilderness in a half an hour. That's pretty special. (Interview 10)

The Mission Range is one of the most beautiful places on earth. It has been long appreciated by the Salish and Kootenai peoples. As wilderness, it remains beautiful and enjoyed by residents and visitors alike.

R: And it's just breathtaking. I mean, it just takes your breath away to set up on top of there and just look in all four directions, and it's just this incredible beauty. (Interview 10) 
R: And it has a big glacier on one side, and it's just this murky looking glacial fed lake and that's because of the sediment is suspended and it's real fine. But it's got its own beauty because, you know, most of the lakes we brag because they're crystal clear... I mean, it's just, every one of them's got a different beauty to it. (Interview 10)

Privacy and seclusion are often expressed as important elements of wilderness places, but solitude is often only a means to an end. These ends can include opportunities to engage in ceremonies, to find time to think, and to escape pressures and stress of everyday life. Tribal members value privacy within the wilderness, and privacy is often necessary.

$R$ : It provides for Native American people that need the seclusion to do ceremonies and to do things that are necessary for spirituality. (Interview 1)

R: And I still, it still brings that same sort of satisfaction to me of being able to get away from society, to get away from the day-to-day, Highway 93, and work, and just sort of feeling the solitude and being alone. (Interview 15)

Although recreation wasn't an activity mentioned extensively by tribal members when asked about what they did in the wilderness, several talked about the importance of providing recreation opportunities.

$R$ : That the modern society's definition of recreation and again is the things like that, you know, hunting, fishing, hiking, camping. And a lot of the people said that's a white man's term, that recreation is not there, not a word that they use. Recreation's what people do when they're messing around. It's not anything serious. It's, you know, off time, leisure, you know. So it's wasted time. And in a lot of people's opinion, it's recreation, you know, you should be busy doing something, doing work, you know. Recreation is thought of that way. (Interview 8)

\section{Nontribal meanings ascribed to the Mission Mountain Tribal Wilderness}

The meanings nontribal members attached to the wilderness are summarized here very similarly to the classification of meanings reported for tribal members to facilitate emphasis on contrasts: (1) environmental protection; (2) functional, emotional, and symbolic attachments; (3) wildlife and watershed protection; and (4) access, beauty, privacy, and recreation.

\section{Environmental protection}

Most nontribal members thought of wilderness protection as the classical federal model, with focus mostly on ecological protection and little, if any, on culture. Protection from roads and development seemed to be the purpose.

I: What do you think is important about the wilderness?

R: Boy, I guess the classic things, that it's land that's just sort of left without the mechanical use. (Interview 14)

$R$ : I think it's kind of neat to have a place where nature can operate without heavy human disturbance. And then I think it's important for all the other reasons that non-Indians think wilderness is important, to preserve biodiversity and to protect fragile resources. (Interview 17)

R1: It's a chunk of real estate that is going to be left pretty much untrammeled by human beings... And this is an opportunity for a unique piece of ecosystem to be maintained for genetic integrities, genetic values. Who knows what kind of a gene pool resides up in this wilderness that might be potentially useful to us as human.... (Interview 5)

Functional, emotional, and symbolic attachments

Nontribal members also reported many attachments to the wilderness, including those that could be described as functional, emotional, and symbolic. Functional reasons aren't subsistence- or cultureoriented, however. For nontribal members, the wilderness is more likely to serve the function of exercise or suggest economic gain.

R: You know, I mean, I left the east when I was 17 and just, so it's been a long time that I've just been hiking in the wildernesses of the west and the east. But I do it for exercise. (Interview 6)

$R$ : And the recreational resource is probably contributing economically to the area because it does have its draw. At trailheads I'm seeing even out-of-state license plates at some of the trailheads. So people are coming to the area, and they're 
probably staying in the motels and eating in the restaurants and they're leaving some cash here, which is good. (Interview 4)

The emotional meanings that nontribal members attached to the wilderness were, of course, from a much more recent past than for tribal members. But many of them dated back to their childhoods. Beyond functional meanings, these emotional attachments were to the place, not necessarily as wilderness, but as a place with which they had a relationship.

R: It goes back when I was a little kid, we used to range those mountains up there... And we ranged those whole mountains when we were seven, eight years old... that's why we worked our way back there trying to find a place to live... we were fortunate enough to find a place. We had to pay a lot of money for it, but we still got it. (Interview 11)

$R:$ I don't even see it as a wilderness anymore. I just see it as my backyard. And a lot of people do, I think. (Interview 6)

The symbolic values that nontribal members placed on the wilderness were in great contrast to the tribal descriptions of the wilderness as an icon, something that connected them to a past when they had freedom to range across many mountain ranges and the protection of their culture for future generations. But nontribal members did seem to recognize the connection to something larger, often describing it as spiritual or religious worship. And sometimes they connected it to a larger U.S. societal recognition of the value of protecting wilderness for all of society, or as symbolic of wise land stewardship.

R2: I think anybody that goes up there, it's spiritual. Doesn't matter what flavor religion you have. When you hike in the Mission Mountains, it's a spiritual thing. (Interview 11)

$R:$ Well, what's important about this wilderness is that this is the first and only, I don't know if it's still the only tribally designated wilderness in the country. I think that's really important. That's really significant, both as a model for other groups of indigenous people, not just in the United States but around the world, to look at how it's done and how it's managed, and that it can be done successfully... To establish a 100,000 acre, well, roughly 100,000 acre wilderness at a local level is pretty remarkable. (Interview 17)

\section{Wildlife and watershed protection}

Nontribal members place great value on the wildlife and the role of the wilderness in protecting it, oftentimes as a refuge to supply animals for them to see in their yards. They don't have the long-term spiritual attraction to the bear, but nevertheless highly value them.

$R$ : There's just about every type of wildlife there is in the west right there. I've seen, right in my yard I've seen grizzly bears and black bears, mountain lions, lynx, wolverines, coyotes, every kind of predatory bird that we have around lives around there. Several species of owls nest up there... mule deer, whitetail, elk, seen all those right in my yard. (Interview 11)

Nontribal members also value the wilderness as a reservoir for water, but more likely for the consumptive values associated with irrigation and domestic uses.

R1: It's protecting headwaters of a lot of streams that are going to end up in irrigation water or domestic water for towns. And that's pretty essential in a semi-arid environment that we live in.

R2: And particularly with a changing climate, we need to protect all the water we can protect because that's going to be one of the limiting resources on how many people can live in this valley. And we're going to see potential water shortages more likely to happen in August than we have in the past, August, September. (Interview 5)

Access, beauty, privacy, and recreation

Some of the nontribal members interviewed moved to the reservation because of jobs, some have always lived there, and some have retired there, mostly for the natural amenities. Access to the wilderness is a valued aspect of their residence locations.

R: And so Ifeel pretty lucky to have such a beautiful place so nearby and a place that's protected. (Interview 17)

"The Missions are gorgeous, they're beautiful, they're really neat." These are some of the adjectives people use to describe the wilderness. Everyone 
agrees it is aesthetically pleasing, and some nontribal members select places to live because of scenic qualities.

$R:$ It's important in that it's a beautiful resource. It's one of the reasons why I was drawn to this area to begin with, to move back here and to make this a permanent home for myself, you know... I think the importance is just the long-term beauty of the place. The long-term recognition that people have when they drive through the Mission area is everyone comments about the Mission Mountains, you know, how rugged they are, how beautiful they are. (Interview 4)

Nontribal members value privacy and seclusion, not for ceremonies, not for hunting, but more as an escape from fences, seeing wildlife, and getting away from noise. In fact, in contrast to tribal members, without cultural meanings attached to the landscape, some nontribal members described it as empty.

$R$ : It's empty, from my perspective, I guess. Just it seems, compared to other places that we've gone, the Sierra or the Cascades or the Front Range, Colorado. It's pretty empty compared to that... Yeah, you don't see very many people at all... I'm trying to think the number of times I've been up there this summer, and I think I've only seen one other party in there in, I don't know, 10, 11 trips in. And even on the weekends you don't see people. (Interview 14)

Nontribal members are more likely to talk about recreation values of the wilderness, and usually in different terms than the tribal members.

R: I just like to go up and, I don't know, I guess get away. It's sort of a, I don't know if it's exactly spiritual, but something on that, just go up, hike around. Go up and bag, bag the bumps, go up on top of the little peaks and... (Interview 14)

R: I don't know. I just like to climb... I like to climb those peaks and get up on top of those peaks and look over the whole world. It's just an enjoyable thing for me. (Interview 3)

R1: For me, the Tribal Wilderness is, has just been such a wonderful playground for myself. (Interview 4)

\section{DISCUSSION AND CONCLUSIONS}

The interviews conducted for this study were not intended to provide results generalizable to the population of the Flathead Indian Reservation, nor any specific part of it. In fact, this phase of a longterm project was intended to provide some background and foundation from which to launch a wider study with more generalizable findings relating mostly to fuel management in the Mission Mountain Tribal Wilderness Buffer Zone. Through intense focus on a small number of people identified for their history with and knowledge about the wilderness, however, in-depth understanding of the range of relationships with the Tribal Wilderness was received.

\section{Contrasting meanings attached to wilderness}

Tribal members and nontribal members differed in the meanings they associate with the wilderness. For tribal members, the focus on protection of nature and culture extended beyond a pristine environment to protection of the traditional relationship that tribal people have with these lands. And although they have had very functional dependencies upon wild places throughout their cultural memories, they have also established some very strong emotional ties to specific places that are protected by the wilderness designation. Cultural and spiritual connectedness values that lie along the ridges and in the stream channels of the Mission Mountains are important to current tribal members and are expected to remain that way. Free-ranging wildlife and water have values beyond subsistence and economic advantage. Particularly valued for its contribution to the lives of bears, the wilderness also is the source of drinkable water and therefore life to the valley below. Tribal members acknowledge a host of appreciative values that are realized by others in the community and travelers through the Mission Valley. The easy access to the wilderness, the scenic beauty of this mountain range, and recreation opportunities are always there and worthy of protection.

Nontribal appreciation of environmental protection is not likely to focus on cultural reasons. Protection from roads and development seem to be the primary protection values, with some appreciation of the intrinsic values of this remote, rugged landscape. The functional meanings of the wilderness to nontribal members were more likely to center on 
exercise or economic benefits. Nontribal members do recognize the symbolic meanings of protected nature, often describing it as a place for religious worship and symbolic of a societal ethic that protects some areas intact. Without the long-term cultural ties to the bear that tribal people have, nontribal people still value them and other wildlife they believe depend upon the wilderness and see the flow of water as important to maintaining high quality of life in lower elevations. And, finally, the nontribal members consistently focus more on recreation and scenic qualities of nature, so easy access to the wilderness contributes substantially to home location decisions.

Others have contrasted human relationships with wildlife, also concluding there is little common ground between Aboriginal and European-based values associated with bears, with great differences in the amount of respect shown through behaviors. Clarke and Slocombe (2009) cited such differences as indigenous people specifically relating through stories why they should never wish to see a bear in order to show respect and avoid conflict. Nontribal residents on the Flathead Reservation, by contrast, attached primary value to the wilderness as producing wildlife with opportunities to view them in their yard.

\section{Contrasting cultural landscapes}

These different meanings attached to the landscape also indicate the very different cultural significance of the socio-cultural decision to protect this landscape as wilderness. Nontribal residents of the reservation seem to conform well to the Eurocentric perspective largely represented in the U.S. Wilderness Act. Recreation, exercise, and exploration in a relatively pristine and uncrowded environment, along with some acknowledgment of ecosystem services provided to wildlife and off-site watershed values are common. Among tribal members, however, the additional cultural significance of this protection, the deep personal and cultural attachments described, and the importance of free-flowing water and free-ranging wildlife contribute to a contrasting set of cultural landscape meanings.

In making decisions about all management policies for the wilderness and adjacent lands, including methods of restoring fire, the tribal government will be faced with the need to understand the full set of meanings attached to this landscape, the threats the people perceive to be priorities for addressing, and work to collaboratively develop actions to ensure sustainability of this unique natural and cultural resource. Of great challenge is to inject the quantitative knowledge accumulated across generations into qualitative management applications, based on respect and reciprocity, as described by Clarke and Slocombe (2009). A focus on protection of cultural landscapes does not necessarily depend on controlled flow of resources but more on resilience of the entire ecosystem, including both human and nonhuman elements. Making potential invisible losses more visible so that decisions can become more transparent in order to protect sustainability of these cultural landscapes is of high priority (Turner et al. 2008).

Responses to this article can be read online at: http://www.ecologyandsociety.org/voll6/iss 1/art36/ responses/

\section{Acknowledgments:}

This project was funded cooperatively by the National Fire Plan, the Bitterroot Ecosystem Management Research Project, The University of Montana College of Forestry \& Conservation, and the Aldo Leopold Wilderness Research Institute, Rocky Mountain Research Station, USDA Forest Service.

\section{LITERATURE CITED}

Basso, K. H. 1996. Wisdom sits in places: landscape and language among the western Apache. University of New Mexico Press, Albuquerque, New Mexico, USA.

Berkes, F. 2008. Sacred ecology. Routledge, New York, New York, USA.

Carlson, P. H. 1998. The Plains Indians. Texas A\&M University Press, College Station, Texas, USA. 
Clarke, D. A., and D. S. Slocombe. 2009. Respect for grizzly bears: an aboriginal approach for coexistence and resilience. Ecology and Society 14(1): 42. [online] URL:http://www.ecologyandsociety.org/ vol14/iss 1/art42.

Dawson, C., and J. C. Hendee. 2009. Wilderness management: stewardship and protection of resources and values. Fourth Edition. Fulcrum, Golden, Colorado, USA.

Garibaldi, A., and N. Turner. 2004. Cultural keystone species: implications for ecological conservation and restoration. Ecology and Society 9(3): 1. [online] URL: http://www.ecologyandsociety. org/vol9/iss3/art1.

Huntington, H. 2002. Can traditional ecological knowledge and wilderness benefit one another? Pages 64-68 in A. E. Watson, L. Alessa, and J. Sproull, editors. Wilderness in the circumpolar North: searching for compatibility in ecological, traditional, and ecotourism values. 2001 May 15-16; Anchorage, Alaska, USA. Proceedings RMRS-P-26. U.S. Department of Agriculture, Forest Service, Rocky Mountain Research Station, Ogden, Utah, USA.

Keller, R. H., and M. F. Turek. 1998. American Indians and National Parks. The University of Arizona Press, Tucson, Arizona, USA.

Küster, H. 2004. Cultural landscapes: an introduction. Pages 1-11 in M. Dieterich and J. van der Straaten, editors. Cultural landscapes and land use: the nature conservation: society interface. Kluwer Academic, Dordrecht, The Netherlands.

Landres, P., D. Cole, and A. Watson. 1994. A monitoring strategy for the National Wilderness Preservation System. Pages 192-197 in J. C. Hendee and V. G. Martin, editors. International wilderness allocation, management, and research. International Wilderness Leadership (WILD) Foundation, Fort Collins, Colorado, USA.

Lewis, J. L., and S. R. J. Sheppard. 2005. Ancient values, new challenges: indigenous spiritual perceptions of landscapes and forest management. Society and Natural Resources 18:907-920.

Martin, V. G. 2006. Eighth World Wilderness Congress generates conservation results. International Journal of Wilderness 11(3):26-29.
Martin, V. G., and A. E. Watson. 2009. Chapter 3: international wilderness. Pages 50-88 in C. Dawson and J. C. Hendee, editors. Wilderness management: stewardship and protection of resources and values. Fourth edition. Fulcrum, Golden, Colorado, USA.

May, T. 2002. Qualitative research in action. Sage, Thousand Oaks, California, USA.

McCool, S. F., and D. N. Cole. 1998. Experiencing limits of acceptable change: some thoughts after a decade of implementation. Pages 72-78 in S. F. $\mathrm{McCool}$ and D. N. Cole, compilers. Proceedings: limits of acceptable change and related planning processes: progress and future directions. 1997 May 20-22; Missoula, Montana, USA. General Technical Report INT-GTR-371. U.S. Department of Agriculture, Forest Service, Rocky Mountain Research Station, Ogden, Utah, USA.

McDonald, T. 1995. Mission Mountains Tribal Wilderness Area of the Flathead Indian Reservation. International Journal of Wilderness Inaugural Issue: 20-21.

Rothenberg, D. 1995. The idea of the wild. Pages 255-277 in V. G. Martin and N. Tyler, compilers. Arctic wilderness: the $5^{\text {th }}$ World Wilderness Congress. North American Press, Golden, Colorado, USA.

Salmon, E. 2000. Kincentric ecology: indigenous perceptions of the human-nature relationship. Ecological Applications 10(5):1327-1332.

Stankey, G. H. 1973. Visitor perception of wilderness recreation carrying capacity. Res. Pap. INT-142. USDA Forest Service, Intermountain Forest and Range Experiment Station, Ogden, Utah, USA.

Stankey, G. H., D. N. Cole, R. C. Lucas, M. E. Petersen, and S. S. Frissell. 1985. The limits of acceptable change (LAC) system for wilderness planning. Gen. Tech. Rep. INT-176. USDA Forest Service, Intermountain Forest and Range Experiment Station, Ogden, Utah, USA.

Tanner, T. 2008. The Mission Mountains Tribal Wilderness Area, U.S.A. Pages 1-24 in J. Cajune, V. G. Martin, and T. Tanner, editors. Protecting wild nature on native lands: case studies by native peoples from around the world. Fulcrum, Golden, Colardo, USA. 
Turner, N. J., M. B. Ignace, and R. Ignace. 2000. Traditional ecological knowledge and wisdom of aboriginal peoples in British Columbia. Ecological Applications 10(5):1275-1287.

Turner, N. J., R. Gregory, C. Brooks, L. Failing, and T. Satterfield. 2008. From invisibility to transparency: identifying the implications. Ecology and Society 13(2): 7. [online] URL: http://www.eco logyandsociety.org/vol13/iss2/art7/.

Watson, A. 1995. An analysis of recent progress in recreation conflict research and perceptions of future challenges and opportunities. Leisure Sciences 17(3): 235-238.

Watson, A. E. 2001. Goal interference and social value differences: understanding wilderness conflicts and implications for managing social density. Pages 62-66 in W. A. Freimund and D. N. Cole, compilers. Visitor use density and wilderness experience. 2001 June 1-3; Missoula, Montana, USA. Proc RMRS-P-20. U.S. Department of Agriculture, Forest Service, Rocky Mountain Research Station, Ogden, Utah, USA.

Watson, A. E. 2004. Human relationships with wilderness: the fundamental definition of wilderness character. International Journal of Wilderness 10(3):4-7.

Watson, A., L. Alessa, and B. Glaspell. 2003. The relationship between traditional ecological knowledge, evolving cultures and wilderness protection in the circumpolar north. Conservation Ecology 8(1): 2. [online] URL:http://www.ecologyandsociety.org/vol8/ iss1/art2.

Watson, A, V. Martin, and C. C. Lin. 2009a. Wilderness: an international community knocking on Asia's door. Journal of National Park (Taiwan) 19(4):1-9.

Watson, A., R. Matt, T. Waters, K. Gunderson, S. Carver, and B. Davis. 2008. Mapping tradeoffs in values at risk at the interface between wilderness and non-wilderness lands. Proceedings: III International Symposium on Fire Economics, Planning, and Policy: Common Problems and Approaches, 29 April-2 May 2008. Carolina, Puerto Rico. General Technical Report PSW-GTR-227. USDA Forest Service, Pacific Southwest Station.
Watson, A., J. Murrieta-Saldivar, and B. McBride, compilers. In press. Science and stewardship to protect and sustain wilderness values: Ninth World Wilderness Congress symposium; 6-13 November 2009; Meridá, Yucatán, Mexico. Proceedings RMRS-P-000. U.S. Department of Agriculture, Forest Service, Rocky Mountain Research Station, Fort Collins, Colorado, USA.

Watson, A., D. Ostergren, P. Fix, B. Overbaugh, D. McCollum, L. Kruger, M. Madsen, and H. Yang. 2009b. Protecting ecotourism resources in a time of rapid economic and environmental transformation in Asia. Pages 185-201 in J. Xiaowen, X. Erming, and I. Schneider, editors. Strategic management engineering: enterprise, environment and crisis. Proceedings of 2009 International Conference on Strategic Management. Sichuan University Press, Chengdu, Sichuan, China.

Watson, A., and D. Williams. 1995. Priorities for human experience research in wilderness. TRENDS/Wilderness Research 32(1):14-18.

Whiting, A. 2004. The relationship between Qikiktagrugmiut (Kotzebue Tribal Members) and the Western Arctic Parklands, Alaska, United States. International Journal of Wilderness 10 (2):28-31, 8 .

Wright, V. 2000. The Aldo Leopold Wilderness Research Institute: a national wilderness research program in support of wilderness management. Pages 260-269 in S. F. McCool, D. N. Cole, W. T. Borrie, and J. O'Loughlin, compilers. Wilderness science in a time of change conference. Volume 3: wilderness as a place for scientific inquiry. 23-27 May 1999. Missoula, Montana, USA. Proceedings RMRS-P-15-VOL-3. U.S. Department of Agriculture, Forest Service, Rocky Mountain Research Station, Ogden, Utah, USA. 